Agropedology 2016, 26 (01) 94-104

\title{
Characterization and Evaluation of Soils Occurring on Toposequence In Eastern Plains, Bhilwara District, Rajasthan for Land Use Planning
}

\author{
R. K. Naitam ${ }^{1 *}$, R. S. Singh ${ }^{1}$, P. C. Moharana ${ }^{1}$ and S. K. Singh ${ }^{2}$ \\ ${ }^{1}$ ICAR-National Bureau of Soil Survey and Land Use Planning, Regional Centre, \\ Udaipur-313 001, India \\ ${ }^{2}$ ICAR-National Bureau of Soil Survey and Land Use Planning, Nagpur-440033, India
}

\begin{abstract}
A reconnaissance soil survey was undertaken at 1:50, 000 scale to characterize and evaluate the land resources of Bhilwara district in Rajasthan for land use planning. Based on landforms seven typifying pedons along the toposequence were studied for their soil-site and physico-chemical characteristics in eastern plain. The study indicates that the soils of steeply sloping hilly terrain were very shallow, excessively drained, dark brown, sandy loam in texture with fine, weak sub-angular blocky structure. The soils of very gently sloping plain and nearly level plain are deep to very deep, imperfectly drained to well drained, olive brown to dark brown soils associated with higher water content at -33 and $-1500 \mathrm{kPa}$ and the organic carbon content was higher in the surface soils compared to subsurface and it decreased with depth. The calcium carbonate content ranged from 1.0 to 36.5 percent and the calcium carbonate content increased with depth. The soils of the hilly terrain (P1) and undulating pediment (P2) have been classified as Lithic Ustorthents and Lithic Haplustepts, respectively. Soils of the intervening valley (P3), undulating plain (P4) and gently sloping plain (P5) categorized as Typic Haplustepts, whereas the soils occurring on the very gently sloping plains (P6) were classified as Vertic Haplustepts. The soils formed on nearly level plain have been classified as Sodic Haplusterts (P7). The soils are grouped under IIes, IIIs, IVes and Ves land capability subclasses and $2 \mathrm{~s}, 3 \mathrm{~s}, 3 \mathrm{st}, 3 \mathrm{sd}$, 4st and $5 \mathrm{st}$ land irrigability sub-classes. The land suitability for major crops growing in the region indicated that the soils of the hilly terrain $(\mathrm{P} 1)$ and undulating pediment $(\mathrm{P} 2)$ are not suitable for most of the crops due to their very severe limitations of slope, erosion and soil depth. The soils of the intervening valley (P3) were moderately suitable for maize and sorghum and marginally suitable for wheat, cotton and mustard. Soils of undulating plain (P4) were highly suitable for maize, sorghum, wheat and moderately suitable for groundnut, cotton and gram. Soils of the gently sloping plains (P5) were highly suitable for sorghum; moderately suitable for maize, wheat, cotton and mustard; and marginally suitable for groundnut and gram. Soils of the very gently sloping plain (P6) were moderately suitable for sorghum and marginally suitable for maize, wheat, cotton and unsuitable for groundnut and gram. Soils of the nearly level plains were moderate to marginally suitable for other crops and unsuitable for groundnut and gram (P7).
\end{abstract}

Keywords: Soil characterization, classifications, Sodic Haplusterts, land capability, land irrigability, soil suitability

\section{Introduction}

Managing soil resources for food security and sustainable environment is gaining great attention considering the increasing pressure on soil due largely to population increase and intensive agricultural production. The modern intensive agriculture which is responsible for a quantum jump in the food grain production and ensured food security, has also led to over exploitation and degradation of natural resources like soil, water, forest, atmosphere and the genetic base. There is a need to develop sustainable soil management systems for achieving target food production from limited soil resources. For sustainable use of the natural resources, a detailed character of land resources giving its potential and constraints becomes prerequisite for planning.

Soils are considered as an integral part of the landscape and thus characteristics are largely governed by the landforms on which they have developed (Sharma et al. 1999). A landform comprises a geomorphological unit and is

Corresponding Author Email: ravindranaitam@gmail.com largely defined by its surface form and location in the landscape. The importance of soil-landform relationship in soil survey and mapping, provide a fair understanding of variability across the landscape needed for sustainable agricultural planning (Murthy 1982). Many researchers studied soil properties with reference to landform position and found significant differences among the soil properties like sand, silt, clay and exchangeable bases. Systematic study of morphology and taxonomy of soils gives idea about nature and type of soils, their constraints, potential capabilities and suitability for various uses (Sehgal 1996). Indiscriminate use of limited soil resources coupled with lack of management has led to degradation causing concern to planners, researchers and farmers. This calls for a scientific approach for development and management of these finite resources at various levels. Hence rational utilization of land resources can be achieved through optimizing its use, which demands evaluation of land for alternative land use. Keeping this in view the present study was carried out to characterize and evaluate the soils of 
eastern plains of Bhilwara district of Rajasthan for alternate land use planning.

\section{Material and Methods}

Study area

Bhilwara district situated in southern part of Rajasthan and lies between $25^{\circ} 1^{\prime}$ and $25^{\circ} 58^{\prime} \mathrm{N}$ latitude and $74^{\circ} 1^{\prime}$ and $75^{\circ} 28^{\prime} \mathrm{E}$ longitude covering an area of 10.45 lakh ha. The district is divided into three major physiographic regions viz. Aravalli landscape, Eastern plain and Vindhyan landscape (Singh et al. 2006). The study area covers Eastern plain having an area of 7.97 lakh ha which is $76.2 \%$ of TGA of the district. The general elevation of the area ranges from 320 to $700 \mathrm{~m}$ above mean sea level (MSL). Agriculture is the dominant occupation for majority of the population. Major crops grown in the area are maize, wheat, sorghum, barley, gram, sesame, groundnut, cotton and mustard. During kharif season, maize is the predominant crop whereas in rabi season wheat and sorghum are predominant. The climate of the district is semi-arid subtropical with dry hot summer and intense winter. The mean annual rainfall of the area is 699 $\mathrm{mm}$, more than 90 percent rainfall received during June to September. The mean annual air temperature varies between $25.6^{\circ} \mathrm{C}$ and $27.1^{\circ} \mathrm{C}$. January is the coldest month with $7.8^{\circ} \mathrm{C}$ and May is the hottest month with $41.5^{\circ} \mathrm{C}$ temperature. The mean annual soil temperature is around $26^{\circ} \mathrm{C}$ with difference of winter and summer temperature being more than $5^{\circ} \mathrm{C}$. Hence, the area qualifies for hyperthermic temperature regime. The soil moisture control section is dry for 90 cumulative days or 45 consecutive days, so the area qualifies for ustic soil moisture regime. Geologically the district is almost underlined by pre-cambrean rocks which consist of Bundelkhand gneiss, banded gneissic complex, Aravalli system, composite gneisses and Vindhyans. However eastern plain composed of Aravalli system covering a wide area in the form of belts and comprises quartzite, conglomerates, shales, slates, phyllites and composite gneiss as apparent material. The natural vegetation of the area comprises of Dhokra (Anogeissus pendula), Khair (Acacia catechu), Dhak (Butea monosperma), Ber (Ziziphus jujube). In some valleys clumps of Bamboo (Dendroealamus strictus) occur while along nullahs Arjuna (Terminalia arjuna) is common.

\section{Methodology}

A reconnaissance soil survey of the district following 3-tier approach (Sehgal et al. 1989) was conducted using SOI toposheet on 1:50,000 in conjunction with visual interpretation of IRS 1B LISS III data on the basis of tone, colour, pattern, texture of the FCC. The entire study area was delineated into different landform units and transformed to the topobase and used during the field survey. Based on interpretation of satellite image and toposheet with ground truth, seven physiographic unit's viz. hilly terrain, undulating pediment, intervening valley and plains were identified (Table 2). Further the plain was subdivided into four land form units on the basis of degree of slope. The soils were studied in different landform units and horizon-wise soil samples were collected and analysed for particle size and calcium carbonate (Piper 1966), soil pH (1:2.5 soil water suspension), exchangeable bases and cation exchange capacity (Jackson 1958), electrical conductivity (Richards 1954), organic carbon (Walkley and Black 1934). The soils were classified as per Keys to Soil Taxonomy (Soil Survey Staff 1998). The soils were grouped under different land capability sub-classes (Klingebiel and Montgomery 1961) and land irrigability sub-classes (AIS\&LUS 1971). The soil site suitability for maize, sorghum, wheat, barley, gram, groundnut and mustard was worked out as per the methodology given in the FAO framework on land evaluation (FAO 1976) modified by Sys et al. (1991).

\section{Results and Discussion}

\section{Morphological characteristics of soils}

The morphological characteristics of the soils occurring on different landforms are given in table 1. The soils of the steeply sloping hilly terrain (P1) are very shallow, excessively drained, dark brown, loamy skeletal in texture with weak aggregation. The soils of the undulating pediment (P2) are shallow, well drained, dark yellowish brown, sandy loam texture with fine weak sub angular blocky structure. The soils of intervening valley (P3) are very deep, well drained, yellowish brown sandy loam soils having fine weak sub angular blocky structure. The soils of undulating plain (P4) occurring on $3-8 \%$ slope are moderately shallow, well drained, brown in colour, sandy loam soils with medium weak sub angular blocky structure. The soils on gently sloping plains (P5) are deep, well drained, dark yellowish brown, sandy loam in texture and medium weak sub angular blocky in structure. The soils of very gently sloping plain (P6) are moderately shallow, well drained, light olive brown in colour and silty clay loam in texture with medium moderate sub angular blocky in structure. These soils have 1 to $2 \mathrm{~cm}$ wide cracks extending up to $32 \mathrm{~cm}$ down the depth. The soils of the nearly level plain $(<1 \%)$ (pedon 7 ) are deep, imperfectly drained, dark brown, clayey soils with massive structure. These soils have 2-5 cm wide cracks, presence of slickensides within first $65 \mathrm{~cm}$ depth and occurrence of soft powdery lime after $115 \mathrm{~cm}$ depth. 


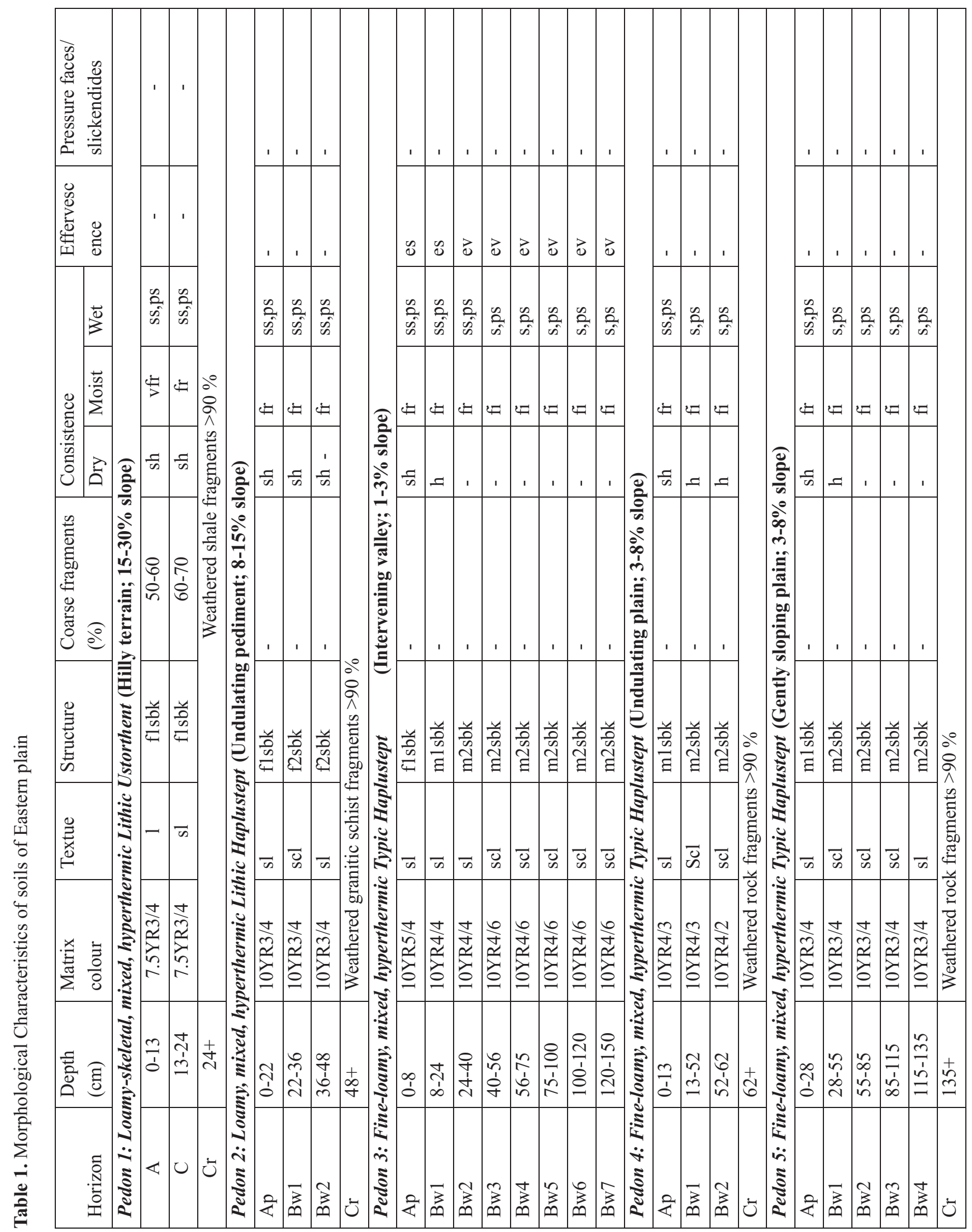




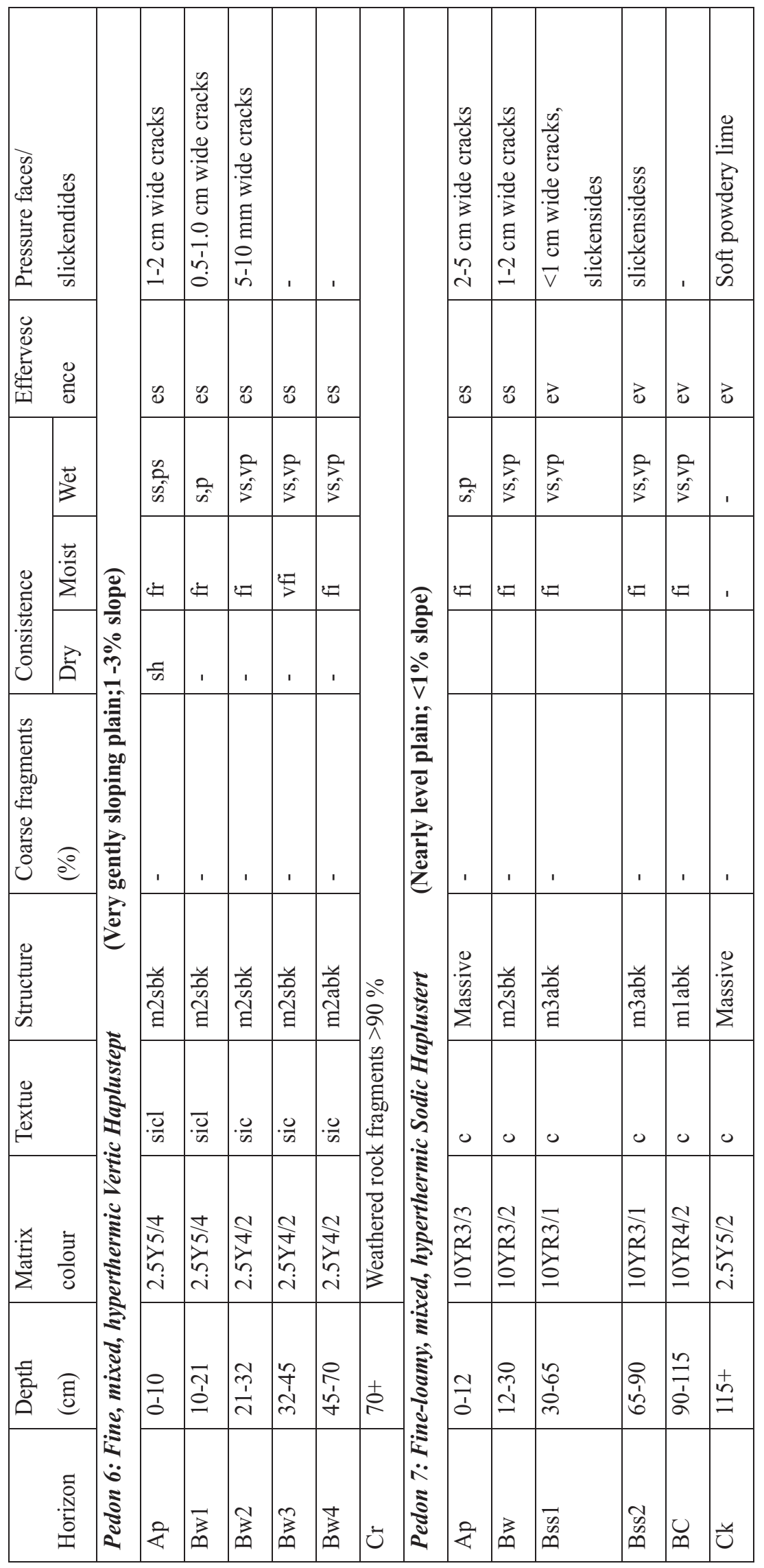




\section{Physical characteristics of soils}

The data pertaining to particle size analysis (Table 2 ) indicate that the sand constitute bulk of the mechanical fraction which could be attributed to the siliceous nature of parent material and its content range from 9.6 (P6) to 78.7 percent (P3).The lowest sand was found in the soils of very gently sloping plain (P6) whereas the highest sand was recorded in nearly level plain (P3) which is formed on the intervening valley. Silt content ranges from 4.3 (P2) to 50.3 (P6) percent and there is no any trend in the distribution of silt down the depth. In general, the clay content was higher in soils occurring on intervening valley (P3), gently sloping plain (P5), very gently sloping plain (P6) and nearly level plain (P7). The clay content varied from 9.2 (P3) to 49.7 (P7) percent and clay content increases with depth in all the soils. Sarkar et al. (2001) and Garhwal et al. (2013) have also found higher clay content in soils occurring on gentler surfaces. The bulk density ranged from $1.3 \mathrm{Mg} \mathrm{m}^{-3}$ (P7) to 1.5 $\mathrm{Mg} \mathrm{m}^{-3}$ (P1, 2, 3, 4 and 5) and increased with depth. The AWC ranges from 5.9 percent (P2) to 23.87 percent (P7). In general the AWC was higher in soils with higher clay content. The higher clay content in soils of very gently sloping plain (P6) and nearly level plain (P7) are associated with higher water content at -33 and $-1500 \mathrm{kPa}$. A significant and positive correlation was observed between clay and moisture retention at $-33 \mathrm{kPa}\left(\mathrm{r}=0.95^{* *}\right)$, clay and moisture retention at $-1500 \mathrm{kPa}(\mathrm{r}=0.94 * *)$ and clay and available water capacity $\left(\mathrm{r}=0.89^{* *}\right)$. The significant and positive correlation between clay and moisture retention at $33 \mathrm{kPa}$ and $-1500 \mathrm{kPa}$ have also been reported by Nagar et al. (1995) and Nagaraju and Gajbhiye (2014).

\section{Chemical characteristics of soils}

The soils of the eastern plain are mildly (P4) to very strongly alkaline (P7) in reaction and values of $\mathrm{pH}$ of the soils ranged from 7.5 to 9.5 and was related to the amount of bases with $\mathrm{pH}$ being higher in soils occurring on gentler slopes (Table 2). The electrical conductivity of the soils ranged from 0.05 (P4) to 2.92 (P7) $\mathrm{dSm}^{-1}$. The organic carbon content was higher in the surface soils and deceased with depth. The calcium carbonate content ranged from 1.1 (P3) to 36.5 (P7) percent. In general, the calcium carbonate content increased with depth (West et al, 1998). Among the exchangeable cations $\mathrm{Ca}^{2+}$ and $\mathrm{Mg}^{2+}$ were the dominant cations followed by $\mathrm{Na}^{+}$and $\mathrm{K}^{+}$. The cation exchange capacity (CEC) ranged from ranged from $9.2(\mathrm{P} 4)$ to $48.4(\mathrm{P} 7) \mathrm{cmol}^{(+)} \mathrm{kg}^{-1}$ depending upon clay content of the representative horizons. Pal et al. (1999) and Challa et al. (2000) have also reported similar findings. The exchangeable sodium percentage (ESP) ranged from 1.7 (P4) to 24.3 (P7) percent and that is associated with topography and swelling type clay minerals. 


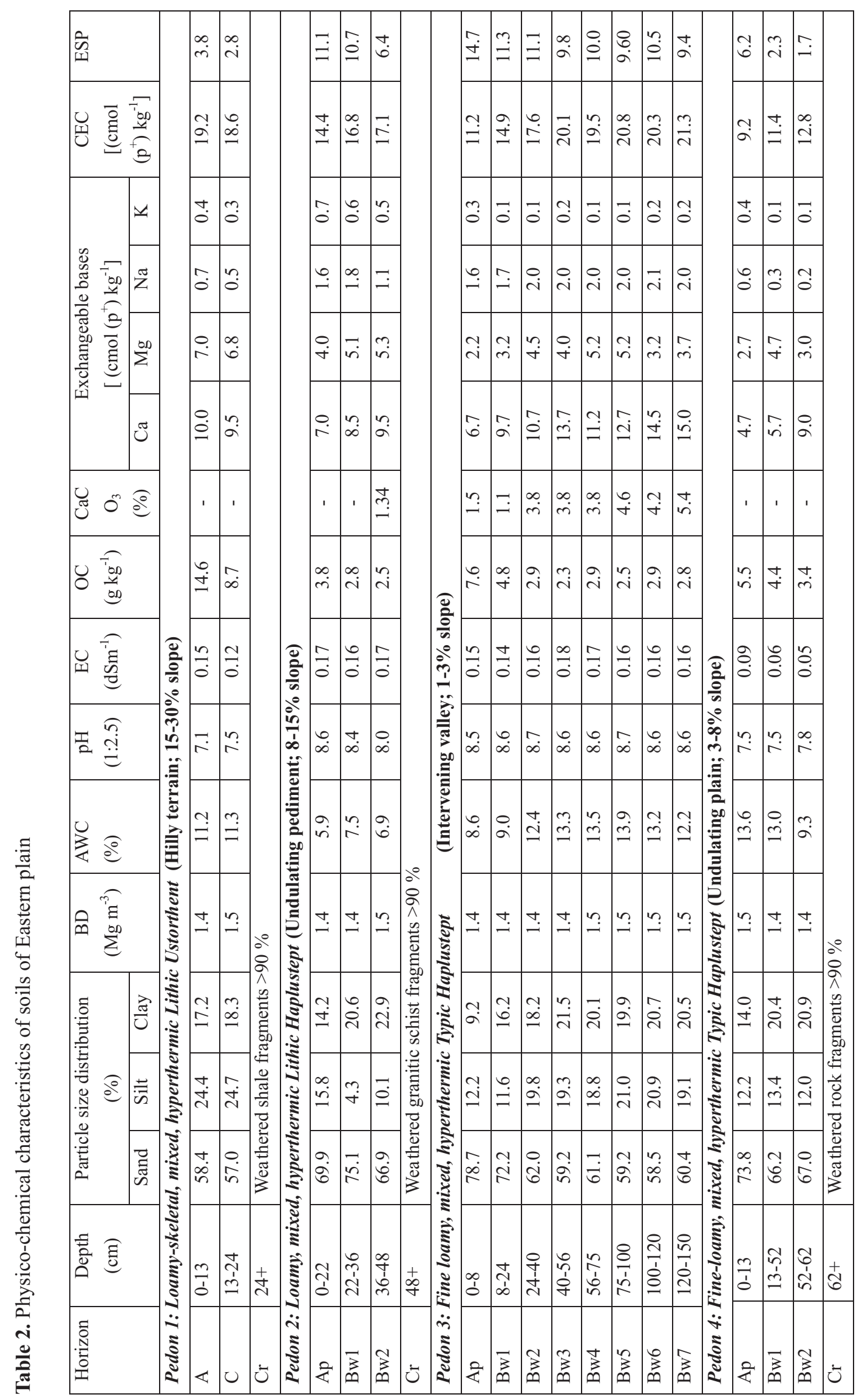




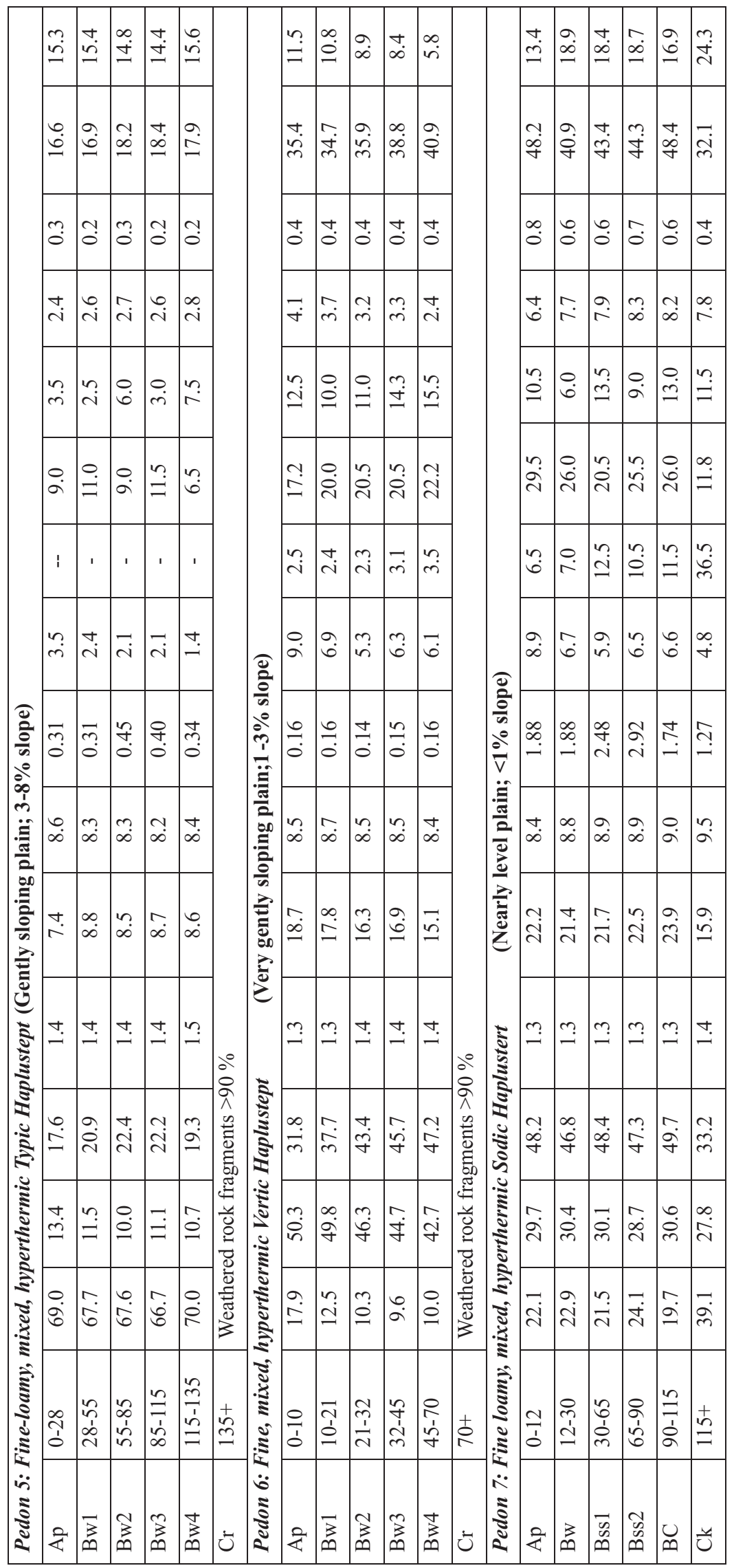


Soil classification

The soils of the eastern plain possess Ustic soil moisture regime, hyperthermic soil temperature regime and mixed mineralogy except pedon 7 . The soils of the pedon 1 are formed on hilly terrain (moderately to steeply sloping land) having 15 to 30 percent slope, due to this most of the fine earth particles are lost by erosion and leaving coarser particles as coarse fragments at the place. By virtue of having lithic contact within the first $50 \mathrm{~cm}$ soil depth and absence of any subsurface diagnostic horizons underlain by Ochric epipedon and presence of 50 to 70 percent coarse fragments compel them to be classify as Loamy-skeletal, mixed, hyperthermic, Lithic Ustorthents. Similarly the soils of the pedon 2 also posses lithic contact within the $50 \mathrm{~cm}$ soil depth but these soils have cambic sub surface horizon showing some sort of development in terms of structure and texture underlain by Ochric epipedon hence these soils are classified as Lithic Haplustepts at subgroup level with loamy textual family class. Soils of the pedon 3, 4 and 5 did not have lithic contact within $50 \mathrm{~cm}$ soil depth from the surface hence these were grouped under Ustept at sub-order level due to ustic soil moisture regime and Haplustept at great group level as these soils posses cambic sub surface horizon underlain by Ochric epipedon and qualified for Typic Haplustepts at sub group level. Soils of the pedon 6 occurring on very gently sloping plains having 1-3 percent slope experiencing Ustic soil moisture regime have been classified as Haplustepts at great group level. In addition to this these soils posses more than 30 percent clay throughout the entire depth with occurrence of 1-2 $\mathrm{cm}$ wide cracks at the surface and that extends up to 30 $\mathrm{cm}$ soil depth without appearance of pressure faces/slickensides that compel these soils to be classify them as Vertic Haplustepts at sub group level. Pedon 7 formed on nearly level plain ( $<1 \%$ slope) and the soils have $2-5 \mathrm{~cm}$ wide cracks at the surface and that extending up to $65 \mathrm{~cm}$ deep with well developed pressure faces and slickensides within $30 \mathrm{~cm}$ soil depth and the clay content more than $30 \%$ throughout depth qualified these soils for Vertisol soil order. Being the ustic soil moisture regime of the area these soils are placed under Haplusterts great group. In addition to this these soils have ESP more than 15 percent within the first $100 \mathrm{~cm}$ soil depth hence these soils are grouped as sodic Haplusterts.
Land capability and land irrigability

The soils are grouped under IIes, IIIs, IVes and Ves land capability sub-classes (Table 3 ). The lands under IIes have few limitations for cultivation with minor soil problems due to moderately shallow depth. The soils are formed on undulating plain with 8-15 slope hence these soils have moderate limitation of slope and erosion. The soils are well drained, sandy loam to clay loam in texture with moderate permeability. The lands under IIIs have moderate limitations of soil such as limitation in terms of sodicity, drainage, texture and nutrient availability in the root zone. The lands under IVes are fairly good cultivable lands having limitations of soil in terms of slope and erosion as these are the soils formed on undulating pediments. The lands of the hilly terrain are grouped under class Ves having severe limitations of soils as these soils pose great problems for cultivation of crops due to their occurrence on $15-30 \%$ slope resulted in severe erosion and very shallow soil depth with 50-60 percent gravels.

The soils are grouped under $2 \mathrm{~s}, 3 \mathrm{~s}, 3 \mathrm{st}, 3 \mathrm{sd}$, 4st and 5 st land irrigability sub-classes (Table 3 ). Lands under class $2 \mathrm{~s}$ have moderate limitations for sustained use under irrigation. These are nearly level to gently sloping lands. Due to soil texture and high $\mathrm{pH}$, these soils have moderate permeability and available water holding capacity. Lands under $3 \mathrm{~s}$, 3sd and $3 \mathrm{st}$ have severe limitations with respect to soil texture, topography, high swelling clay and $\mathrm{pH}$ associated with sodicity resulting in to poor permeability and poor drainage. The main constraints in these soils are undulating topography and deterioration of physical properties of these soils. The lands under $4 \mathrm{~s}$ and 4 st classes are marginally suitable for sustained use under irrigation with severe limitations of texture, depth and slope associated with the topography. In case of 4st land leveling operations also may not work in these soils as the soils are situated on undulating pediments. The lands which are grouped as temporarily not suitable for sustained use under irrigation are 5 st. These are the soils of hilly terrain having 15-30 percent slope and severe limitations of soil depth and erosion. 
Table 3. Land capability, land irrigability and soil-site suitability for different crops

\begin{tabular}{|c|c|c|c|c|c|c|c|c|c|}
\hline \multirow[t]{2}{*}{ Pedon } & \multirow{2}{*}{$\begin{array}{l}\text { Land capability } \\
\text { sub-class }\end{array}$} & \multirow{2}{*}{$\begin{array}{l}\text { Land irrigability } \\
\text { sub-class }\end{array}$} & \multicolumn{7}{|c|}{ Soil suitability rating } \\
\hline & & & Maize & Sorghum & Wheat & Groundnut & Cotton & Gram & Mustard \\
\hline 1 & Ves & 5 st & $\mathrm{N}$ & $\mathrm{N}$ & $\mathrm{N}$ & $\mathrm{N}$ & $\mathrm{N}$ & $\mathrm{N}$ & $\mathrm{N}$ \\
\hline 2 & IVes & $4 \mathrm{st}$ & S3 & S3 & $\mathrm{N}$ & $\mathrm{N}$ & $\mathrm{N}$ & $\mathrm{N}$ & $\mathrm{N}$ \\
\hline 3 & IIIs & $3 \mathrm{~s}$ & S2 & S2 & S3 & $\mathrm{N}$ & S3 & $\mathrm{N}$ & S3 \\
\hline 4 & IIes & $3 \mathrm{st}$ & S1 & S1 & S1 & S2 & S2 & S2 & S1 \\
\hline 5 & IIIs & $2 \mathrm{~s}$ & S2 & S1 & S2 & S3 & S2 & S3 & S2 \\
\hline 6 & IIIs & $2 \mathrm{~s}$ & S3 & S2 & S3 & $\mathrm{N}$ & S3 & $\mathrm{N}$ & S3 \\
\hline 7 & IIIs & $3 \mathrm{sd}$ & S3 & S2 & S3 & $\mathrm{N}$ & $\mathrm{S} 2$ & $\mathrm{~N}$ & S3 \\
\hline
\end{tabular}

\section{Suitability of soils for crops}

The suitability of soils for maize, sorghum, wheat, groundnut, cotton, gram and mustard is presented in Table 3. The data indicates that the soils of pedon 1 are not suitable for cultivation of any arable crops due to their severe limitations of topography, slope, erosion, depth and their skeletal nature; soils of pedon 4 are highly suitable for maize cultivation as these soils are well drained and favorable soil texture for luxuriant growth of maize. Soils of pedon 3 and 5 are moderately suitable due to moderate limitations of texture, $\mathrm{pH}, \mathrm{CEC}$ and soil organic carbon. On the other hand, soils of pedon 2, 6 and 7 are marginally suitable for maize crops as the these soils have dominant limitations of soil depth, heavy clay texture imposing problem of drainage with adverse physical and chemical properties like high ESP and sodicity. Suitability for sorghum indicates that soils of pedon 4 and 5 are highly suitable due to their soil depth, drainage, texture, $\mathrm{pH}, \mathrm{CEC}$ and organic carbon content; whereas the soils of pedon 3, 6 and 7 are moderately suitable for sorghum due to moderate limitation of drainage, water logging, clay texture, low CEC and organic carbon content. Soils of pedon 2 are marginally suitable for sorghum due to their severe limitations of effective rooting depth, low CEC and higher slope. Wheat is one of the major rabi crop grown in the region, hence the soils were evaluated for suitability for wheat crop. Soils of the pedon 1 and 2 having very severe limitations of slope, erosion, soil depth and their hilly and undulating topographic position are not suitable for wheat cultivation.
Soils of the pedon 4 having favorable climatic conditions along with supplemental irrigation with sandy clay loam texture and well drainage proved to be a highly suitable soils for wheat; whereas the soils of the pedon 5 are moderately suitable for wheat with moderate limitations of texture, $\mathrm{pH}$ and organic carbon. Pedon 3, 6 and 7 soils have severe limitation of low $\mathrm{CEC}$, high $\mathrm{pH}$, clay texture, poor drainage and sodicity. The suitability of soils for growing groundnut indicates that soils of pedon 1,2, 3, 6 and 7 are not suitable due to their severe limitation of slope, erosion, clay texture, soil depth, drainage and sodicity makes them non suitable for groundnut. Soils of the pedon 4 are moderately suitable for groundnut with moderate limitations of depth and texture. On the contrary soils of pedon 5 have severe limitations of texture, $\mathrm{pH}$ and sodicity therefore these soils are marginally suitable for groundnut cultivation. Cotton is one of the most important commercial cash crop of India with very deep rooting system and nutrient exhaustive nature. Suitability evaluation for cotton showed that soils of pedon 1 and 2 have very severe limitation of slope, erosion and rooting depth therefore these soils are classified as not suitable for cotton. Soils of pedon 4, 5 and 7 are moderately suitable for cotton as these soils have moderate limitations of climatic regime, effective rooting depth, drainage, $\mathrm{pH}$, organic carbon and sodicity. Pedon 3 and 6 soils are having severe limitations of drainage, $\mathrm{pH}$, texture, $\mathrm{CEC}$ and organic carbon hence these soils are marginally suitable for cotton cultivation. Suitability for gram indicates that soils of pedon 1, 2, 3,6 and 7 are not suitable due to their very severe limitations of climatic 
requirement, slope, erosion, depth, drainage texture and sodicity; however soils of pedon 2 with moderate limitations of depth, erosion and soil texture are moderately suitable for gram. Pedon 5 have severe limitations of drainage and texture for gram cultivation hence these soils are marginally suitable for gram. Mustard is one of the important oil seed crop in the region and the soil suitability for mustard indicates that soils of pedon 1 and 2 have very severe limitations of slope, erosion and effective rooting depth. Therefore these soils are classified as not suitable for mustard. Soils of the pedon 4 have favorable drainage, soil texture, $\mathrm{pH}$ and organic carbon content for cultivation of mustard hence these soils are put under S1 class, soils of pedon 5 have moderate limitations of drainage, texture and organic carbon that's why these soils are moderately suitable for mustard. On the other hand soils of pedon 3, 6 and 7 have severe limitations of drainage, soil texture, $\mathrm{pH}$ and sodicity therefore these soils are put under moderately suitable class.

\section{Conclusions}

The study of morphological, physical and chemical analysis of soils along the toposequence on eastern plain in Bhilwara district of Rajasthan revealed that the soils occurring on different landform showed variation in the soil properties. The soils of the steeply sloping hilly terrain were very shallow, excessively drained, dark brown, sandy loam in texture with fine, weak sub angular blocky structure. The soils of very gently sloping plain and nearly level plain are higher in clay content that is associated with high available water capacity and CEC. The study also indicated that the variation in topography have played an important role in modifying the properties of soils in terms of soil depth and clay content with $\mathrm{Na}^{+}$as dominant cation on the exchange complex in the soils of nearly level Plains. The soils of the eastern plain were classified as Lithic Ustorthents, Lithic Haplustepts, Typic Haplustepts, Vertic Haplustepts and Sodic Haplusterts. The soils are grouped under IIes, IIIs, IVes and Ves land capability sub-classes and $2 \mathrm{~s}, 3 \mathrm{~s}, 3 \mathrm{st}, 3 \mathrm{sd}$, 4st and 5 st land irrigability sub-classes. The soils of the hilly terrain and undulating pediment were not suitable for most of the crops due to their very severe limitations of slope, erosion and soil depth. The soils of the intervening valley were moderately suitable for maize and sorghum. Soils of undulating plain were highly suitable for maize, sorghum, wheat. Soils of the gently sloping plains were highly suitable for sorghum. Soils of the very gently sloping plain were moderate to marginally suitable for most of the crops. Soils of the nearly level plains were highly suitable for maize and sorghum; moderate to marginally suitable for other crops and unsuitable for groundnut and gram.

\section{References:}

AIS\&LUS (All India Soil and Land Use Survey) (1971). Soil Survey Manual (Revised Edition), IARI, New Delhi. 121 p.

Challa, O., Bhaskar, B.P., Anantwar, S.G. and Gaikwad, M.S. (2000). Characterization and classification of some problematic Vertisols in semi-arid ecosystem of Maharashtra plateau. Journal of Indian Society of Soil Science 48:139-145.

FAO (1976). Framework for Land Evaluation. Soils Bulletin No. 32. (Food and Agriculture Organization : Rome)

Garhwal, R.S., Qureshi, F.M. and Giri, J. D. (2013). Characterization and classification of the soils of Sirohi district of Rajasthan. Agropedology 23(1):815.

Jackson, M. L. (1958). Soil Chemical Analysis. Prentice Hall, Englewood Chiffs, New Jersy, 498.

Klingebiel, A.A. and Montgomery, P.H. (1961). Land capability classification. Agric. Handbook 210 (USDA. Soil Conservation Service. Washington, D.C.)

Murthy, R.S., Hirekerur, L.R., Deshpande, S.B., and Venkat Rao, B.V. (eds.) (1982). Benchmark Soils of India: Morphology, characteristics and classification for resource management. NBSS Publ. 1982, 374p.

Nagar, R.P., Gupta, R.K., Karkansi, P.T., Sharma, S.P. and Saxena, S. (1995). Soil water characteristics of different soil series in Chambal command area of Rajasthan. Journal of Indian Society of Soil Science 44:329-334.

Nagaraju, M.S.S and Gajbhiye, K.S. (2014). Characeterization and evaluation of soils of Kukdi Command (Minor-25) in Ahmednagar district of Maharashtra for land resource management. Agropedology 24 (02): 157-165.

Pal, D.K., Dasog, G.S., Vadivelu, S., Ahuja, R.L. and Bhattacharyya, T. (1999). Secondary calcium carbonates in soils of arid and semi-arid regions of India. In: Global climate change and pedogenic carbonate (Rattan Lal, John M. Kimble, H. Eswaran and B.A. Stewart Eds). Lewis Publishers, NY. 
Piper, C. S. (1966). Soil and Plant Analysis. Hans Publishers, Bombay.

Richards, L.A. (eds.), (1954). Diagnosis and improvement of saline and alkali soils, USDA Agric. Handbook 60, U.S. Govt. Printing Office, Washington, D.C.: 160. Sarkar, D. Gangopadhyay, S.K. and Velayutham, M. (2001).

Soil toposequence relationship and classification in lower outlier of Chhotanagpur plateau. Agropedology 11: 29-36.

Sehgal, J.L., (1996). Pedology: Concepts and Applications, Kalyani Publishers, New Delhi.

Sharma, R.C., Mandal, A.K., Saxena, R.K. and Verma, K.S. (1999). Characterization, formation and reclamability of sodic soils under different geomorphic plains of Ganga basin. Extended Summary, International Conference on Sustainable Management of Sodic Lands, Feb 9-4, 2004, Lukhnow, India Vol.I, pp 168-170.
Singh, R.S., Jain, B.L., Giri, J.D. and Shyampura, R.L. (2006). Soils of Bhilwara district for land use planning. NBSS Publ. No. 135, NBSS\&LUP, Nagpur, pp. 239.

Soil Survey Staff (1998). Keys to Soil Taxonomy, 8th Ed. SCS, USDA. Washington, D.C.

Sys, C.E., Van Ranst and Debayeve (1991). Land Evaluation, Part I and II. Re-edited volumes of Publication No. 7. (General Administration of Cooperation and Development, Brussels, Belgium).

Walkley, A. and Black, I.A. (1934). An examination of Degtjareff method for determining soil organic matter and proposal modification of the chromic acid titration method. Soil Science 37: 29-38.

Received: February, 2016 Accepted : May, 2016 